\title{
Ophidascaris durissus sp. nov. (Nematoda Ascarididae) parasitizing Crotalus durissus Linnaeus (Ophidia, Viperidae) in Brazil
}

\section{Marcia Helena Martins Panizzutti 1, 2, Leonilda Correia dos Santos ${ }^{3}$, Joaquim Júlio Vicente ${ }^{1}$, Luís Cláudio Muniz-Pereira ${ }^{1} \&$ Roberto Magalhães Pinto ${ }^{1,4}$}

\author{
1 Laboratório de Helmintos Parasitos de Vertebrados, Departamento de Helmintologia, Instituto Oswaldo Cruz. \\ Avenida Brasil 4365, 21045-900 Rio de Janeiro, Rio de Janeiro, Brasil. \\ 2 Instituto de Biologia do Exército (IBEX), Subdivisão Serpentário. Rio de Janeiro, Rio de Janeiro, Brasil. \\ ${ }^{3}$ Laboratório Ambiental, Departamento de Meio Ambiente Físico, Itaipu-Binacional. Foz do Iguaçu, Brasil.
}

\begin{abstract}
The species Ophidascaris durissus sp. nov. is proposed with basis on specimens recovered from the rattlesnake Crotalus durissus L., 1758 (type host) captured in Foz do Iguaçu, Brazil (type locality). By the lack of interlabia, the new species can be compared only to O. natricis Yamaguti, 1935 from Japan and O. freitasi Hoa $8 \times$ Lien, 1970, from Vietnam. However, 0 . durissus sp. nov. differs from O. natricis mainly by the absence of internal lip papillae, location of the vulvar aperture and length of the spicules; from 0 . freitasi mostly by the greater number of pre-cloacal and distribution of post-cloacal papillae.
\end{abstract}

KEY WORDS. Brazil, Crotalus durissus, Nematoda, Ophidascars durissus sp. nov., Ophidia, rattlesnake.

Ascaridoid nematodes of Ophidascaris Baylis, 1921 are commonly found parasitizing snakes worldwide. This paper reports to the description of $O$. durissus sp. nov., with basis on nematodes recovered from the rattlesnake Crotalus durissus L., 1758 , in Brazil.

\section{MATERIALS AND METHODS}

In August 1997, sixteen adult (eight males and eight females) and seven immature (four males and three females) nematodes were recovered from one specimen of the rattlesnake Crotalus durissus Linnaeus, 1758 found dead in the area of the Itaipu Binacional Reserve, Foz do Iguaçu, State of Paraná, Brazil.

Nematodes were fixed in hot $70^{\circ} \mathrm{GL}$ ethanol and processed for study as described elsewhere (PINTO et al. 2001). Measurements are in millimeters, unless otherwise indicated, with means in parenthesis. "En face" jelly mounts were obtained in accordance with ANDERSon (1958). Figures were made with the aid of a drawing tube connected to a Olympus microscope. Type and voucher specimens were deposited in the Helminthological Collection of the Oswaldo Cruz Institute (CHIOC), preserved as whole mounts or as wet material.

\footnotetext{
${ }^{4} \mathrm{CNPq}$ research fellow. Corresponding author. E-mail: rmpinto@ioc.fiocruz.br
}

\section{RESULTS \\ Ophidascaris durissus sp. nov.}

Figs. 1-7

Description: based on eight males and eight females. Ascarididae. Males: body 52-68 (60.8) long, 0.61-0.76 (0.67) wide.

Mouth common to the ascaridoids, with three lips, the dorsal bearing two large outer papillae and the latero-ventral with one papilla each. The lips present indentations in the internal borders. Interlabia absent. Esophagus 3.08-3.99 (3.63) long. Nerve ring and excretory pore 0.63-0.74 (0.67) and 0.67$0.88(0.70)$ from the anterior end, respectively. Spicules subequal, alate, 2.94-2.90 (2.53) long. The difference in length between the spicules can reach 0.35 (0.28). Caudal alae narrow. At least 70 pairs of pre-cloacal papillae, one pair of ad-cloacal and six pairs of post-cloacal papillae. Tail 0.21-0.27 (0.23) long.

Females: body 56-93 (67.8) long, 0.56-0.83 (0.70) wide. Mouth as referred for the males. Esophagus 3.40-4.84 (4.26) long. Nerve ring and excretory pore 0.59-0.80 (0.70) and 0.780.87 (0.82), from the anterior end, respectively. Vulvar aperture opening into a short ovijector (vagina vera), bifurcates at 1.121.26 (1.23) from its origin; vulvar slit lies between the beginning and half portion of middle third of the body, 31.3-43.7 (37.5) from posterior extremity. Didelphic, ophistodelphic; genital apparatus located in posterior half of body. Eggs subspherical, 


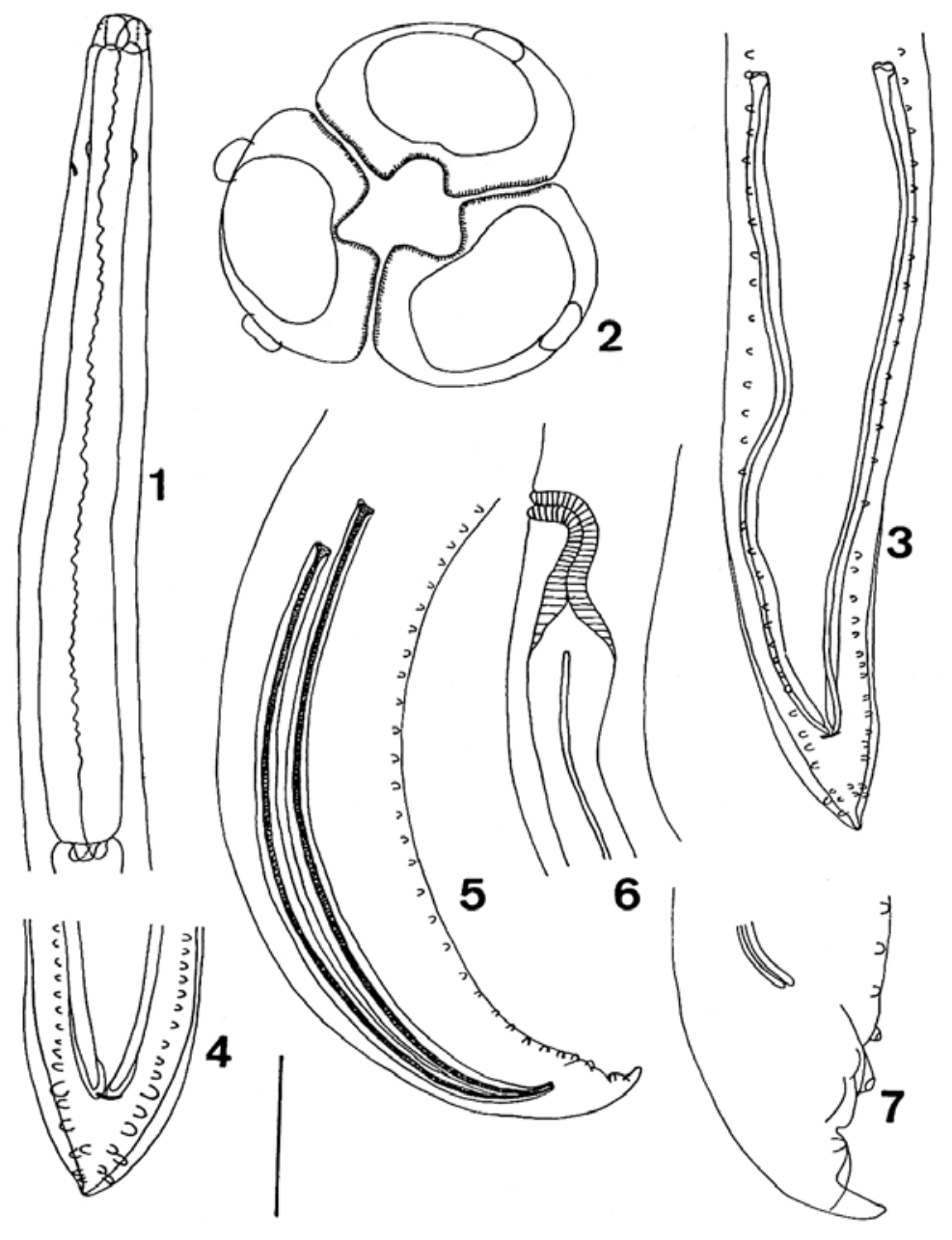

Figuras 1-7. Ophidascaris durissus sp. nov. (1) anterior portion of male, lateral view; (2) head of female, "en face" view; (3) posterior portion of male, ventral view; (4) posterior extremity of male, ventral view; (5) posterior portion of male, lateral view; (6) vulvar region, lateral view; (7) posterior extremity of male, lateral view. Bar (common to Figs. 1-7) =0.08 mm in Fig. 2; $0.5 \mathrm{~mm}$ in Figs. 3, 5, 7; $0.7 \mathrm{~mm}$ in Figs. 1, 4, 6.

00.05-0.07 long x 0.068-0.084 wide. Anus 0.24-0.45 (0.34) from posterior extremity.Tail slender, with conical end.

Type host: Crotalus durissus Linnaeus, 1758 (Ophidia, Viperidae); common names: rattlesnake, "cascavel".

Site of infection: stomach.

Type locality: Itaipu Binacional Reserve, Foz do Iguaçu, Brazil-Paraguay border, State of Paraná, Brazil $\left(24^{\circ} 05^{\prime}-25^{\circ} 33^{\prime} \mathrm{S}\right.$, $\left.54^{\circ} 00^{\prime}-54^{\circ} 37^{\prime} \mathrm{W}\right)$.

Specimens deposited: CHIOC no. 34937 a (holotype), 34937 b-f (paratypes) (whole mounts), 34687 (vouchers) (wet material). durissus.

Etymology: the new species is named after the host $C$.

Revista Brasileira de Zoologia 20 (1): 9-11, março 2003

\section{REMARKS}

Ophidascaris durissus sp. nov. is the first Brazilian species of the genus without interlabia. This character alone, limits the comparison of the new species with only two other ophidascarids with this same morphological aspect: Ophidascaris natricis Yamaguti, 1935, parasitizing Rhabdophis tigrinus (Boie, 1826) ( = Natrix tigrina) and Elaphe quadrivirgata (Boie, 1826) from Japan and O. freitasi Hoa \& Lien, 1970, recovered from Xenochrophis piscator (Schneider, 1799) ( = Natrix piscator) from Vietnam.

Ophidascaris durissus sp. nov. differs from O. natricis proposed by Yamaguti (1935), mainly by the length of the spicules, a reliable distinguishing parameter, that in the new 
species, is twice the size obtained for the spicules of specimens of $O$. natricis. Moreover, the internal lip papillae, found on the top of the three anterior lobes of the esophagus in $O$. natricis are absent in $O$. durissus sp. nov. In O. natricis the vulva lies in the posterior half of the middle third of the body, whereas in the new species the vulvar aperture opens either in the anterior half or middle portion of this region.

From O. freitasi, proposed by HoA \& LIEN (1970), O. durissus sp. nov. differs for the greater number of pre-cloacal papillae (at least 70 pairs in the new species, compared to 36-40 in $O$. freitasi), arrangement of the six pairs of post-cloacal papillae that are continuously disposed in bilateral rows in $O$. durissus sp. nov. whereas in $O$. freitasi, with a total of five pairs, there are two pairs immediately after the cloacal aperture that appear to be somewhat fused and isolated from the other three. The additional pair of pre-cloacal papillae observed in $O$. durissus sp. nov. was not considered, since the comparison was made on the basis of the pattern of papillae distribution.

Another point refers to the length of the ovijector (vagina vera) of females of $O$. durissus sp. nov. when compared to the illustrated for $O$. freitasi, that is of $1.2 \mathrm{~mm}$ in the former and $7.0 \mathrm{~mm}$ in the latter. However, this parameter was not taken into account, since HoA \& LIEN (1970) did not clearly refer to the length of the ovijector in the text; the obtained value (present paper) was calculated with basis on the figure bar only and thus, considered unreliable.

The other species of the genus referred in C. durissus are: Ophidascaris travassosi Vaz, 1938 and O. sprenti Araujo, 1969
(VICENTE et al. 1993). However, these authors listing the species of the genus referred in Brazilian snakes, overlooked data after Freitas (1968) and refer erroneously to C. trichuriformis Vaz, 1935, parasitizing C. durissus.

\section{REFERENCES}

Anderson, R.C. 1958. Méthode pour l'examen des nématodes em vue apicale. Annales de Parasitologie Humaine et Comparée, Paris, 33: 171-172.

Freitas, J.F.T. 1968. Revisão do gênero Ophidascaris Baylis, 1921 (Nematoda, Ascaridoidea). Memórias do Instituto Oswaldo Cruz, Rio de Janeiro, 66: 1-83.

HoA, L.V. \& N.T. LiEN. 1970. Um nouvel ascaride, Ophidascaris freitasi sp. nov. parasite de Natrix piscator (Schlegel) du Sud Viet-Nam. Bulletin de la Societé de Pathologie Exotique, Paris, 3: 382-387.

Pinto, R.M.; L. Gonçalves; D. Noronha \& D.C. Gomes. 2001. Worm burdens in outbred and inbred laboratory rats with morphometric data on Syphacia muris (Yamaguti, 1935) Yamaguti, 1941 (Nematoda, Oxyuroidea). Memórias do Instituto Oswaldo Cruz, Rio de Janeiro, 96: 133-136.

Vicente, J.J.; H.O. Rodrigues; D.C. Gomes \& R.M. Pinto. 1993. Nematóides do Brasil. Parte III: Nematóides de répteis. Revista Brasileira de Zoologia 10 (1): 19-168.

Yamaguti, S. 1935. Studies on the helminth fauna of Japan. Part 11. Reptilian nematodes. Japanese Journal of Zoology, Tokyo, 6: 393-402.

Received in 30.IX.2002; accepted in 19.II.2003. 